\title{
Communicative Culture Formation of Future Social Workers in the Educational Process of Pedagogical University
}

\author{
Svitlana Omelchenko ${ }^{1}$, Nadiia Chernukha ${ }^{2}$, Yaroslav Spivak ${ }^{1}$ Liudmyla Spivak $^{1} \&$ Elmira Uteubaeva ${ }^{3}$ \\ ${ }^{1}$ Donbas State Pedagogical University, Slovyansk, Ukraine \\ ${ }^{2}$ Taras Shevchenko National University of Kyiv, Ukraine \\ ${ }^{3}$ E. A. Buketov Karaganda State University, Kazakhstan \\ Correspondence: Mariana Mateeva Petrova, St.Cyril and St.Methodius University of Veliko Tarnovo, Bulgaria.
}

Received: May 22, 2020

doi:10.5430/ijhe.v9n4p283
Accepted: June 22, 2020

Online Published: June 25, 2020

\begin{abstract}
Article considers the essence of the process of communicative culture formation of future social workers in the educational process of the pedagogical university. The communicative culture is singled out and considered through an interdisciplinary approach in the professional education of social workers. The peculiarities of the communicative culture formation of future social workers in the educational process in the pedagogical university are highlighted. Emphasis is placed on the need to use various tools in the phenomenon under study, such as: verbal, non-verbal, information and communication. The students' attitude to the process of communicative culture formation of future social workers in the educational process of the pedagogical university are investigated. The results of the experimental study are described.
\end{abstract}

Keywords: professional education, social worker, verbal communication, nonverbal communication, information and communication

\section{Introduction}

Communicative culture is a fundamental characteristic of the professional competence of a social worker. The implementation of the professional competence of a social worker takes place in various types of its activities, such as: establishing, supporting and developing effective interaction with the client or other participants in the social process. The communicative competence formation of social worker is a movement from the actual world of personal events to the results of awareness of these events. The obligatory position is that these events are fixed in the cognitive structures of the psyche in the form of skills and serve the individual in additional contact with others.

The ability to participate in communicative situations increases in accordance with the assimilation of individual cultural, including ideological and moral norms and patterns of public life. Given the characteristics of the professional competence of a social worker, we can assume that communicative culture is part of the communicative competence of a social worker. It means that the communicative culture of future social worker is a holistic, dynamic personal formation that ensures its adaptation and self-realization in modern society.

Social work is a field of scientific knowledge and professional activity aimed at maintaining and providing qualified assistance to any person, group of people, community, which expands or restores their ability to social functioning, promotes the realization of civil rights, prevents social exclusion. Social work as a professional activity is an interconnected system of values, theory and practice. Its mission is to give people the opportunity to develop their full potential, enrich their lives and prevent dysfunction (Bondarenko,2004).

We consider it necessary to note that the peculiarity of social work is related to the solution of problems that arise and relate to a particular person, it directly or indirectly covers all forms and types of social relations and human activities.

We emphasize that the communicative culture of a social worker is one of the main means of his professional activity, and should be done in such a way as to quickly establish contact with one person or group of people, catch the mood, define attitudes and expectations, persuade and inspire and constantly maintain positive active position of interaction, as well as to combine and comprehensively apply the main components of communicative competence. 
Given this, the problem of forming a communicative culture of future social workers in pedagogical university is relevant and requires scientific and practical solution.

\section{Analysis of the Research and Publications}

It should be noted that the professional training of social workers is a complex of knowledge, skills, abilities, values, psychological qualities, professional positions and acmeological options. At the same time, the professional competence of a social worker should be considered a core component of his chosen activity, and communicative culture - a necessary condition for its effectiveness (Levitska, 2011).

Analysis of the training of social workers shows that the content and forms of education do not always correlate with the social, cultural, political, psychological features of reality (Petrova,Buzko\& Dyachenko, 2018),(Chupryakova, Zakonnova\&Petrova, 2020),(Linde \&Petrova, 2019),(Levashova,2010), (Koval et al, 2018). This creates obstacles to the scientific understanding of the specifics of the work of a social worker, hinders the development of future professionals, makes the learning process far from practical professional needs.

Modern scientific research (Popova, 2016), shows that the professional training of social workers for professional communication with all objects of social work is the most important component, as future professionals need to be taught to establish language contact with clients, find out their true problems, accumulate and understand their verbal and nonverbal information, to effectively influence customers.

Bulgarian and foreign researchers (Nenkov et al, 2017), (Petrova, Tepavicharova \&Dikova, 2019),(Uteubayev, Petrova \& Lyubenova, 2018),(Valdmane et al, 2020),(Tepavicharova, Dikova \&Zahars, 2019),(Lazarova et al, 2015) show significant results in the comprehension and structuring of this subject.

In this context, notable publications such as (Lazarova et al, 2015), (Zagorodnya et al, 2020), (Baklanova, Petrova\& Koval, 2020), (Petrova et al, 2020), (Hlibko et al, 2019), (Jarmusevicaet al, 2019A), (Jarmusevicaet al, 2019B) are to be singled out.

The analysis of universities' curricula gives us a possibility to make a suggestion that there are small number of hours devoted to the formation of communication skills. And so it arises scattering of communicative knowledge in the disciplines of both the humanities and the block of professional and special disciplines.

The absence of the insufficient methodological basis creates a problem of processing and dissemination of relevant research and experience in this area in educational institutions, objective assessment of proposed learning technologies and study possible ways improving the quality of communicative training of graduates (Pavliuk, 2017).

The educational process should be aimed at developing future social workers' skills, in particular, communicative culture in the educational process of pedagogical university. It should be noted that social workers are also clients of social services and other social institutions, and they need the support of social services who are ready and able to understand and help them (Diachok, 2019).

\section{Methods}

The purpose of the article is to highlight and substantiate the importance of a process of the communicative culture forming of future social workers in the educational process of the Pedagogical University.

Objectives of the study:

1 method of analysis and synthesis (in order to reveal the conceptual and categorical apparatus of research and scientific substantiation of modern areas of professional education of the future social workers);

2 scientific abstraction, induction and deduction (during the generalization of domestic and foreign experience in the use of modern educational technologies by future social workers);

3 abstract-logical (for theoretical generalization of research results and formulation of conclusions);

4 a survey was conducted using the "Google Survey" system among students of Taras Shevchenko National University of Kyiv and Donbas State Pedagogical University;

5 special methods: mathematical and statistical processing of research results - for the analysis of the received data, ranking, scaling, registration, systematization and differentiation, grouping, graphic expression of data. 


\section{Results and Discussions}

The social worker interacts with a large number of sources of information, not one specific field, but many: receives legal information, economic, medical, social, pedagogical. The nature of the social worker constantly puts him in a communicative position, requiring him to identify socio-psychological characteristics that promote interpersonal interaction. It is necessary to note that professional competence is primarily socio-psychological qualities of future social workers, and therefore they should be considered professionally significant. Therefore, the solution of many pedagogical problems of professional activity depends on the level of communicative competence of the social worker.

Given into account the experience of communicative culture forming of future social workers in the educational process of the Pedagogical University, we consider it necessary to sing out this experience abroad, to identify proposals for improving the training of future social workers in Ukraine. Analysis of higher education and the profession of social work, allowed scientists to identify strengths, such as: a holistic focus on practice; the relationship between theory and practice; regulation and certification; universal approach to practice; increasing the cultural relevance of social work education; quality social work programs; constant demand for social workers; and the values of the profession.

It is necessary to highlight in detail the process of forming the communicative culture of future social workers in the educational process of the Pedagogical University. The formed communicative culture of a social worker provides qualified assistance to a person, group of people or community through communication, support of direct and indirect contacts, through understanding of the client.

It is necessary to single out some features of communicative culture formation of the future social workers in the educational process of the Pedagogical University: knowledge of features of oral and written norms of literary language in the field of personal and professional communication, rules of registration of business documents, features of carrying out business negotiations, etc.; ability to use two forms of business speech: oral and written, adhere to the norms of modern literary language, logically and consistently formulate opinions, speak a foreign language orally and in writing, compose business letters, agreements, contracts, etc., read, have a conversation in the professional sphere, work with linguistic and reference literature, use certain language tools depending on the circumstances, participate in international cooperation, exchange scientific and professional experience, establish personal and professional contacts, be professionally mobile, express their point of view, listen and understand the interlocutor's vision, lead a discussion; solve communicative tasks, behave adequately in different socio-cultural situations, have ways of formal reasoning and argumentation.

Note that the formed communicative culture helps the future social worker to establish and maintain the necessary contacts with other people; master a set of professional skills.

It is distinguished that the professional development of a social worker and the formation of their communicative culture occurs through their knowledge of certain social norms and rules of communication, adaptive skills as conditions for achieving effective relationships. (Godlevskaya, 2007; Kobzar, 1998).

Properly formed communicative culture of future social workers implements the most important principles of social work, which is necessary for professional activity in a multinational environment: legality and human rights, tolerance, humanism, communication, universality, protection of social rights, confidentiality and social response (Ryabova, 2019).

The analysis of foreign experience allowed us to conclude that the preparation of communicative culture forming of future social workers in the educational process abroad has its advantages. But these advantages include a reverse side: lack of professional identification or identity crisis; inability to advance the profession; diffuse knowledge base of the profession; conflict between the values of social action and social control; insufficient preparation for stress management of our work; insufficient number of aborigines, visible minority and multicultural members of the profession (Westhues, 2001).

A professional education faces with a difficult task to be able to improve the level of communicative culture of future social workers during the educational process at the Pedagogical University. To do this, the focus must be on the person whose safety and standard of living, rights and well-being need to be improved. Therefore, the formation of the communicative culture of the future social worker should be given the most important role in higher education institutions. To solve this problem, we need to require all experience, knowledge that has been accumulated in our country and abroad and which social workers must learn for using in practice and developing in further professional activities. 


\section{Results Analysis}

A survey was conducted using the "Google Survey" system among students of Taras Shevchenko National University of Kyiv and Donbas State Pedagogical University.

The purpose of this survey was to determine the features of the communicative culture formation of the future social workers in the educational process of the Pedagogical University. The survey was attended by students of III and IV years of the first (bachelor's) educational level. The total number of respondents was 78 people.

The results of the survey helped to represent the following statistics.

The process of forming a communicative culture should take into account modern approaches to the development of a culture of interpersonal relationships, as this will be the basis for considering human interaction with other actors. In turn, this feature will help to form communicative culture more effective than it was. (Fig. 1).

\section{Is communication culture important for a social worker?}

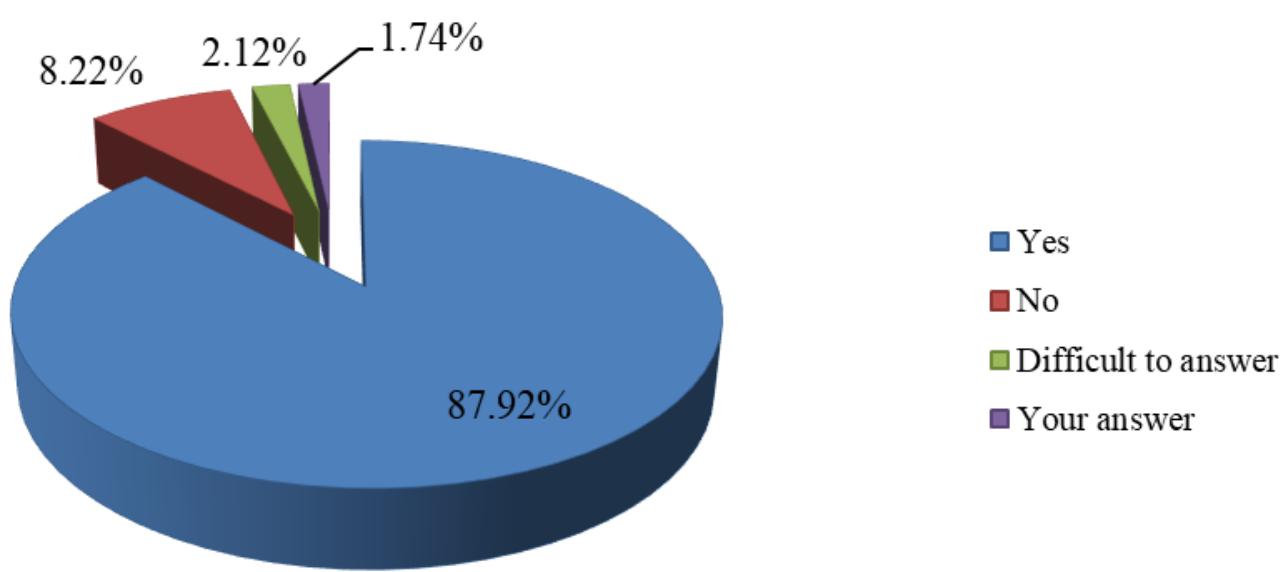

Figure 1. Is communication culture important for a social worker?

\section{Source: developed by the authors}

It should be noted that modern approaches to the development of the communicative culture will help to overcome the problem in the modern social sphere, such as long-term communication. It should be noted that today long-term communication with social workers creates many conflict situations that need a constructive solution.

Quite interesting was the reaction of students to the question: does communicative culture characterize the professional level of a social worker? Statistical data showed that communicative culture in the process we studied, students identified as a necessary feature in the formation of professional competence of social workers in the educational process of the Pedagogical University (Figure 2).

From so, we can make the assumption that the communicative culture of the future employee is a complex socio-pedagogical phenomenon consisting of several interrelated components (communicative guidelines, knowledge, communication skills, which are implemented under certain conditions and depend on external conditions and internal factors).

Thus, the process of forming the communicative culture of future social workers in the educational process of the Pedagogical University should be aimed at the ability to quickly adapt to non-standard professional situations. 
Does communicative culture characterize the professional level of a social worker?

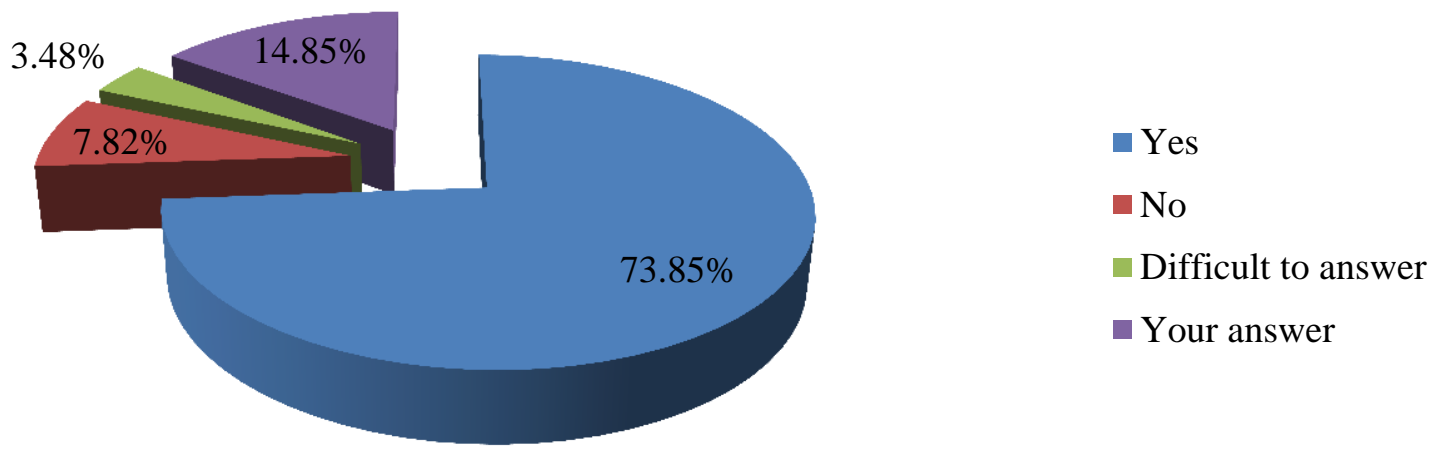

Figure 2. Does communicative culture characterize the professional level of a social worker?

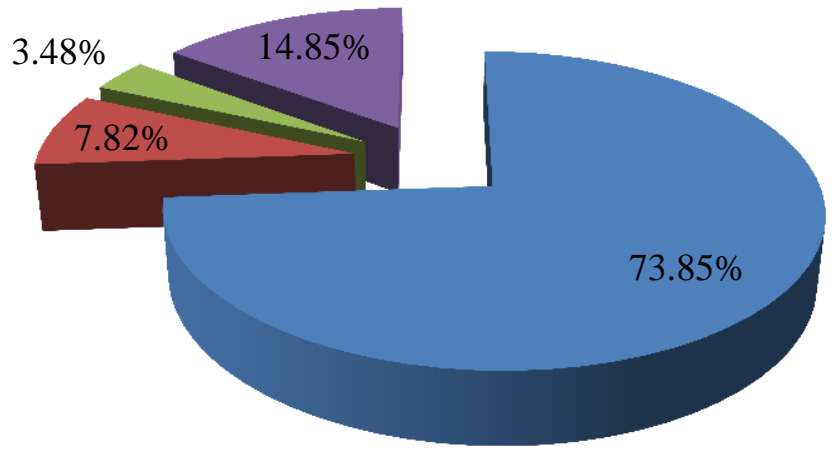

- Yes

- No

Difficult to answer

- Your answer

Source: developed by the authors

Communicative culture in the process of collective action

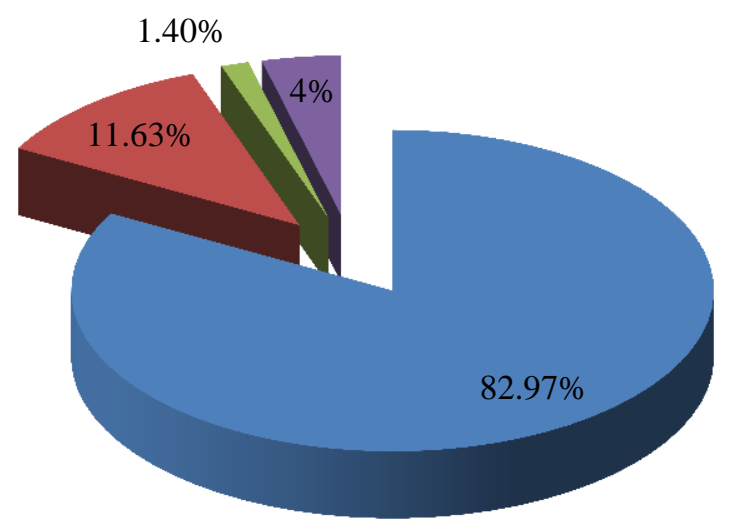

- Yes

- Hi

Difficult to answer

- Your answer

Figure 3. Communicative culture in the process of collective action

Source: developed by the authors 
The communicative culture formation of the future social workers during collective actions involves the improvement of relations between humans and includes a set of norms that reflect the level of work organization and maturity of intra-collective relations.

The process of forming a communicative culture during the collective actions in the educational process of the Pedagogical University makes it possible to master the prompt and timely execution of orders in accordance with the requests of teachers, and later both clients and employers.

The communicative culture of the future social worker should include the use of verbal and nonverbal, information and communication mean of information exchange (Fig. 4).

\section{Preparetion of what kind of communication shoud be better in the professional education of social workers?}

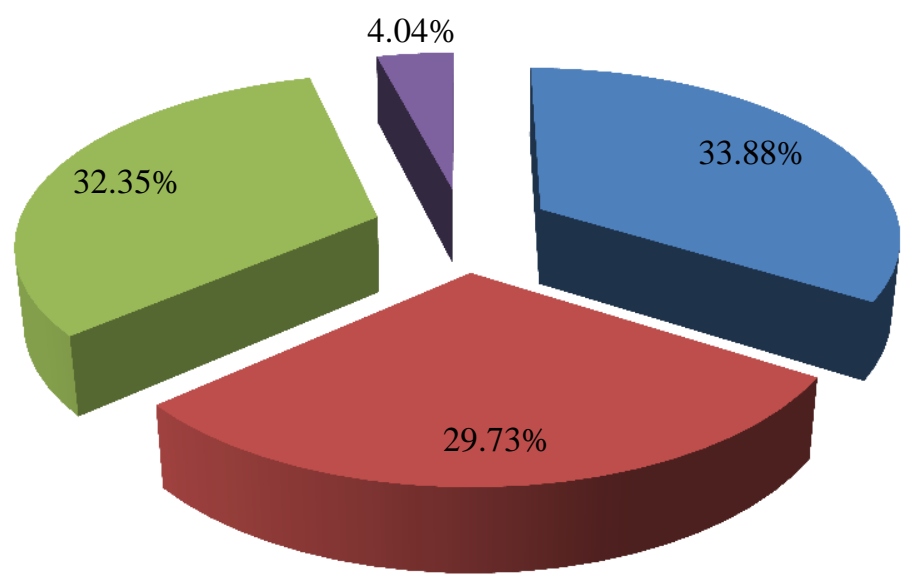

- Verbal

nonverbal

- Informational or comunicational

- Your answer

Figure 4. Preparetion of what kind of communication shoud be better in the professional education of social workers?

\section{Source: developed by the authors}

Statistical analysis of the survey allowed us to conclude that the communicative culture of future social workers in the educational process of the Pedagogical University involves the formation of certain skills and abilities of students, such as: (depth, completeness, thoroughness, awareness, etc.). The successful process of formation of the phenomenon studied by us in the process of professional training should be ensured by rational use of the latest pedagogical technologies, realization of interrelations of aesthetic, psychological, culturological knowledge and professional skills, taking into account international requirements to professional competence of social workers.

\section{Conclusions}

The communicative culture formation of the future social workers starts in the educational process of the Pedagogical University and is based on their specifics. It means that future social worker will have the ability to provide social assistance, based not on general but on theoretical and practical knowledge and skills, taking into account the potential clients of social institutions.

In order for the process of the communicative culture forming of future social workers in the educational process of the pedagogical institute to become more effective, it must be improved. To make better the process we are studying, we should pay attention to improving the professional education of social workers. To pay special attention to the communicative culture formation of the future social worker during the educational process at the Pedagogical University is a necessary condition for all areas of work with people.

The formed communicative culture with all its features will help to overcome certain psychological and social barriers between all objects of social work and potential clients of social institutions. 
Future social workers must become a skilled and competitive workforce, but to do so they need to skillfully and effectively use the opportunities provided by the educational environment of the pedagogical university. In fact, this place teaches future professionals to adapt to rapidly changing working conditions.

\section{References}

Badjanova, J., Ilisko, Dz., Petrova, M. (2018). Definition and Dynamics of Gender-Specific Behaviours of Latvian Males and Females. Rural Environment. Education. Personality (REEP). (2018). Proceedings of the International Scientific Conference, 11, 11th - 12th May 2018. Jelgava: Latvia University of Life Sciences and Technologies. Faculty of Engineering. Institute of Education and Home Economics. ISSN 2255-8071, Jelgava, LATVIA, 11.-12.05.2018, 53-58. https://doi.org/10.22616/REEP.2018.005

Baklanova, O., Petrova, M., Koval, V. (2020). Institutional transmission in economic development, Ikonomicheski Izsledvania (Economic Studies), 29(1), 68-91.

Beddoe, L. (2011). Investing in the Future: Social Workers Talk about Research. [in English]. The British Journal of Social Work, 4l(3), 557-575. https://doi.org/10.1093/bjsw/bcq138

Bondarenko, N. B, Griga IM, Kabachenko NV Fundamentals of social work Part 1. (2204). Part 1.178 p. [in Ukrainian].

Chupryakova, A., Zakonnova, L., Petrova, M. (2020). Benchmarking as a determinant of modern mining education.E3S Web of Conferences (2020). $V^{\text {th }}$ International Innovative Mining Symposium, IIMS 2020, T.F. Gorbachev Kuzbass State Technical University, Kemerovo, Russian Federation. https://doi.org/10.1051/e3sconf/202017404053

Diachok, N., Chernukha, N., Tokaruk, L., Udovenko, I., Petrova, M. (2020). PRACTICAL-ORIENTED CONCEPT AS A PRINCIPLE OF PROFESSIONAL EDUCATION OF THE FUTURE PROFESSIONALS. International Journal of Higher Education, 9(4), August 2020, 233-234. https://doi.org/10.5430/ijhe.v9n4p233

Godlevskaya,D. M. (2007) Formation of professional communicative competence of future social workers in the conditions of pedagogical university.Candidate's thesis (Social pedagogic). Kyiv [in Ukrainian]. [Electronic resource] http://enpuir.npu.edu.ua/handle/123456789/1407 (accessed:16/05/2020)

Hlibko, S.V.,Vnukova, N.N., Hontar, D.D., Anisimova, H.V.,Liubchych, A.N. (2019). Risk-oriented approach to determining bank's capital size according to requirements of basel committee on banking supervision, Ikonomicheski Izsledvania, 28(1), 2019, 56-71.

Jarmusevica, V.; Ilisko, D.; Badjanova, J.; Jukss, V.; Petrova (2019). M. SMART governance of implementing the strategy of corporate societal responsibility for a sustainable regional development. International Multidisciplinary Scientific GeoConference Surveying Geology and Mining Ecology Management, SGEM 19(5.3), 645-652. https://doi.org/10.5593/sgem2019/5.3/S21.081

Jarmusevica, V.; Ilisko, D.; Badjanova, J.; Jukss, V.; Petrova, M. (2019B). Educating citizens for integrating the strategy of corporate social responsibility for sustainable regional development: the case study. Proceedings of EDULEARN19 Conference 1st-3rd July 2019, Palma, Mallorca, Spain, 10449-10454. https://library.iated.org/view/JARMUSEVICA2019EDU,ISSN:2340-1117. https://doi.org/10.21125/edulearn.2019.2633

Kobzar, T. L. Communicative competence: a psychological approach to the problem [in Ukrainian]. [Electronic resource] //http: //eprints.zu.edu.ua/375/2/C1B26889.pdf. (accessed:16/05/2020)

Koval V., Polyezhaev Y., \& Bezkhlibna A. 2018. Communicative competences in enhancing of regional competitiveness in the labour market. Baltic Journal of Economic Studies, 4(5), 105-113. https://doi.org/10.30525/2256-0742/2018-4-5-105-113

Kurbatov, V.I. (1999). Sotsialna robota [Social work]. Rostov N/D, 576 p. [in Russian].

Lazarova, T., Zhelyazkova, V., Vazov, R. (2015). Innovation leadership as a key concept in entrepreneurship. The 8th International Conference for Entrepreneurship, Innovation and Regional Development. 18th and 19th June 2015 Conference proceedings, University of Sheffield

Levashova L.(2010).Problemy zarzązania kapitałem ludzkim - wyzwania współczesności, Wydawnictwo L\&J Techtrading sp. z o.o., Warszawa,70 p.

Levitska, N. S. Moskalenko V. V. Peculiarities of social-perceptual competence of social workers [in Ukrainian]. 
[Electronic resource] http://ir.stu.cn.ua/123456789/6050 (accessed:16/05/2020)

Linde I.,Petrova M. (2018).The challenges of Formalization and Modeling of Higher Education Institutions in the 21st century.CBU International Conference Proceedings 2018: Innovations in Science and Education. 303-308. https://doi.org/10.12955/cbup.v6.1173

Nenkov N., Dyachenko Y., Petrova M., Bondarenko G. \& V. Pustovit. (2017). Intelligent and Cognitive Technologies in Education of International Economic Relations Students and Human Resource Development in Enterprises: Methodology in Language. European Journal of Sustainable Development. Publisher: European Center of Sustainable Development. Rome, Italy, 6(4), 2017, 353-360. https://doi.org/10.14207/ejsd.2017.v6n4p353

Pavliuk, R. O.; Liakh, T. L.; Bezpalko, O. V.; Klishevych, N. A. (2017). Research-based training: methodological characteristics and results of the analysis of educational programs. [in English]. Social Sciences, 6(4), 152. https://doi.org/10.3390/socsci6040152

Petrova M., Buzko I, Dyachenko Yu. (2018). Cognitive, Intelligence Technologies and Economical Foundations of Teaching of International Economical Relations and Tourism. 17th International Scientific Conference ERDev, 23.-25.05.2018. Jelgava, latvia, 1102-1106. https://doi.org/10.22616/ERDev2018.17.N170

Petrova, M., Tepavicharova, M., Dikova, L. (2019). Factors for development of the educational and professional qualification profile of the human resources in the machine building sector in Bulgaria. ISPCIME-2019. MATEC Web of Conferences, 297(06015). https://doi.org/10.1051/matecconf/201929706001

Petrova, M., Koval, V., Tepavicharova, M., Zerkal,A., Radchenko, A., Bondarchuk, N. 2020. The interaction between the human resources motivation and the commitment to the organizations. Journal of Security and Sustainability Issues, 9(3). http://doi.org/10.9770/jssi.2020.9.3(15)

Popova L. Possibilities for coping with professional stress in teachers. Economics \& Education. (2016). Riga, Latvia, l(1). 33-35. https://ee.isma.lv/issues/E_E_0101/09_E_E_0101_Popova.pdf

Ryabova, Y. (2019) Foundations and principles of future social workers training to the professional activity in the multinational environment [in Ukrainian]. [Electronic resource],http://mir.dspu.edu.ua/article/view/176115/175935. https://doi.org/10.24919/2308-4634.2019.176115(accessed:12/05/2020)

Tepavicharova, M., Dikova, L., Zahars, V. (2019). Development of a competency model for selection of human resources in the mining and quarrying sector in Bulgaria. I $V^{\text {th }}$ International Innovative Mining SymposiumE3S Web of Conferences, 105. Ed. by Tyulenev M.; Zhironkin S.; Khoreshok A.; Vöth S.; Cehlár M.; Nuray D.; Janocko J.; Anyona S.; Tan Y.; Abay A.; Marasová D.; StefanekP. October 14-16, Kemerovo, Russian Federation. https://doi.org/10.1051/e3sconf/201910504029

Uteubayev, T., Petrova M.M., Lyubenova, I. (2018).Training of qualified specialists in the process of their education at the university: the role of the public-private partnership. CBU International Conference Proceedings 2018: Innovations in Science and Education, 491-495. https://doi.org/10.12955/cbup.v6.1203

Valdmane, L., Zarina, S., Iliško, D., Badjanova, J., Petrova, M. (2020). Empowering of Digital and media literacy of primary school teachers in Latvia. EDULEARN20,12th annual International Conference on Education and New Learning Technologies, 6th - 7th of July, 2020 (inprint)

Westhues, A. A., Lafrance, J., Schmidt, G. (2001, February). SWOT analysis of social work education in Canada. [in English]. [Electronic resource] https://doi.org/10.1080/02615470020028364. https://www.researchgate.net/publication/248994170_A_SWOT_analysis_of_social_work_education_in_Canad a. (accessed:10/05/2020)

Zagorodnya, A., Dichek, N., Chobitko, N., Voznyk, M., Honchar, L., Petrova, M. (2020). Professional training of the economic sector specialists at higher education institutions of the Republic of Poland and Ukraine: criteria of comparison. International Journal of Higher Education, 9(3), June 2020, 139-144. https://doi.org/10.5430/ijhe.v9n3p139 